\title{
Information Technology Components and Their Role in Knowledge Management for Product Design
}

\author{
Mariam Ibrahim and Ma Huimin
}

\begin{abstract}
The present study aims to discuss the role of the information technology (IT) components (hardware, software and network) in knowledge management for product design. Data were collected through questionnaires, which were distributed 220 questionnaires to industrial companies in China. Simple regression analyses were used to determine the relationship between hardware and knowledge management , software and knowledge management, network and knowledge management, knowledge management and product design, also Multiple regression analyses were used to determine the relationship among hardware, software, network, knowledge management and product design, Results of the statistical analysis showed that the components of information management, knowledge management, and product design had a significant positive correlation, which suggests a strong relationship. Moreover, information management components, which support knowledge management, plays a vital role in product design to achieve competitive advantage. Therefore, companies must use information and knowledge management in obtaining their objectives to achieve a competitive advantage in their product design and be consistent with customer requirements to achieve consumer satisfaction. Product design does not only involve field product, and operations management or simple management participation. The foundation of product design the proper use of IT components are valuable knowledge.
\end{abstract}

Index Terms-IT components. knowledge management, product design.

\section{CRITICAL REVIEW}

How does IT affect product design and why? The literature suggests that the mediating factor between IT and product design is knowledge management [1]. Designing products well, integrating the performance of the company in the production process, and reducing the costs in an unstable technology environment, make a company efficient by using IT and knowledge management [2], [3]. IT helps solve many difficulties during product design, including the vast amount of external information and market changes to organize, analyze, and make appropriate decisions [4]. Knowledge is information results after evaluation, organize and benefit from its [5]. Critical knowledge is a source of competitive advantage for a company. Given the important role it plays in product design, intervention in the early stages of product design collects and analyzes information, evaluates, and sieves [6]. companies provides important location to

Manuscript received December 29, 2016; revised February 20, 2017.

Mariam Ibrahim is with Business Administration at the School of Management, HUST, China, (e-mail: Mariama.hamood@uokufa.edu.iq).

Ma Huimin is with the Department of Information Management, School of Management, HUST, China (e-mail: Ma_huimin@hust.edi.cn). knowledge management because of the globalization of work and the increasing use of IT, wherein the production base transitions to the knowledge base, and production must be changed in accordance with the continuous developments, it cannot be fixed [7]. The most prominent manifestation of the development of IT, wherein researchers did not experience any difference, are in the following components: hardware, software, and networks, [8] which are the focus of the current study. IT components, which complement their tangible and intangible instruments in enhancing the work environment, achieve increased satisfaction to internal and external customers and competitive advantage [9]. IT link directly and indirectly affects the product design through the mediating factor (knowledge management). An IT component enhances knowledge management at a company. Knowledge management then creates and exploits the compatibility among the product, customer, and managerial knowledge in the company [10]. Where we note that most of the companies are using information technology, knowledge management in the design of their products, but there are companies is out of the market early time, and some remains, but does not achieve a competitive advantage, and others achieve a competitive advantage. Through this research, we aim to clarify these links and relationships, and explain the effects of IT components effect on knowledge management, and knowledge management on product design.

\section{RESEARCH MODEL AND HyPOTHESES}

Fig. 1 shows the proposed model in this research, which consists of five variable: hardware, software, networks, knowledge management, and product design. IT is influenced by its components on knowledge management and directly affects product design.

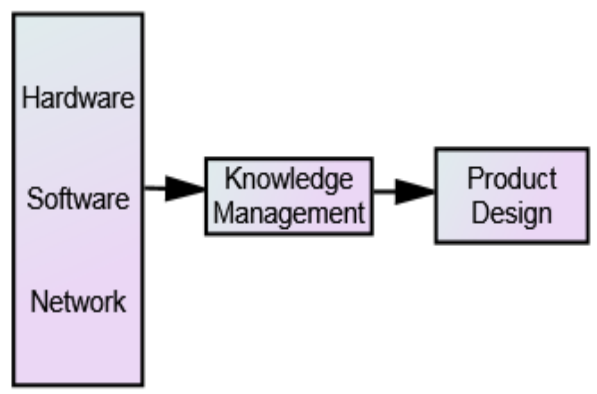

Fig. 1. Model proposed research.

\section{A. IT Components}

IT is a key factor in knowledge management [11]; it records, saves knowledge, and communicates through hardware, software, and networks [12]. 


\section{1) Hardware and software}

Hardware and software cannot be isolated from knowledge management, where knowledge management depends directly on the efficiency of hardware and software to perform its operations and make the right decisions [13]. Thus, the following hypotheses are drawn:

H1: A positive relationship exists between hardware and knowledge management.

H2: A positive relationship exists between software and knowledge management.

\section{2) Network}

Networks are necessary for knowledge management to help obtain knowledge, maximize efficiency, and gain benefits [14]. Thus, the following hypotheses are derived: H3: A positive relationship exists between knowledge management and product design.

\section{B. Knowledge Management}

Knowledge management is the organization and establishment of cooperation, in addition to activities related to creation, conservation, and distribution. Knowledge assets, which are timely and sufficient, provide support and information exchange, and prevent information overload [15] Organizational capability, as well as the transport and distribution of knowledge, can be a competitive advantage after identification, creation, or acquisition of knowledge [16]. Knowledge management leads to making the right decisions, solving problems quickly, minimizing the number of errors and their frequencies, reducing research cost, developing and enhancing customer relationship, and improving production; it help companies create, acquire, transfer, and distribute important information and experiences [17]. Knowledge management is effective and supports products [18].

Previous studies on the effect of creating knowledge on product designs have confirmed that knowledge management is a fundamental factor for firm success [19]; thus, we arrive at the following hypothesis.

H4: A positive relationship exists between knowledge management and product design.

\section{Product Design}

Product design represents a process; knowledge of structure and components of the product from the available relevant information are considered the input for product design given that product requirement factors are part of the product knowledge [20]. Therefore, knowledge and experience designers affect the product design process, where designers translate their ideas, draw the initial design, and discuss it [21]. As confirmed previously [22], knowledge management supports the design process by providing a knowledge database that can store and retrieve information, evaluate the product design, make the final decision in accordance with the customer requirements and design constraints, and neglect unacceptable product design alternatives. IT is also considered as the source or basis of knowledge; we need to generate production management activities as products and equipment; it is the ability to select, acquire, generate, and apply technology that meets the goals of the company [23]. Therefore, a relationship exists between knowledge management and product design, which plays an important role in influencing the products to meet customer needs, especially large investments for research and development with good performance [24]. that IT component achieves customer satisfaction by offering products meeting their needs and desires, which affects KM in providing these products through the design [25]Thus:

H5: A positive relationship exists among hardware, software, network, knowledge management, and product design.

\section{RESEARCH METHODOLOGY}

\section{A. Data and Sample}

Data were collected through a questionnaire using a five-point Likert scale, which ranges from strongly disagree (1) to strongly agree (5). The questions were answered and analyzed using an SPSS system.

The private sample determines the failure and success of the study. This sample is the reason for date generation to analyze and test the hypotheses through accurate answers using the questionnaire items. A total of 220 questionnaires were distributed to selected company managers, and department heads, engineers, designers, and employees related to product design in Chinese companies. Table I describes the research sample.

\begin{tabular}{|c|c|c|c|}
\hline variable & Category & number & percent \\
\hline \multirow{5}{*}{$\begin{array}{c}\text { The Enterprise } \\
\text { Type }\end{array}$} & Private & 20 & 9.1 \\
\hline & Joint-stock & 20 & 9.1 \\
\hline & State-owned & 140 & 63.6 \\
\hline & Joint venture & 20 & 9.1 \\
\hline & Foreign-funded & 20 & 9.1 \\
\hline \multirow{2}{*}{$\begin{array}{l}\text { Period of the } \\
\text { enterprise } \\
\text { development }\end{array}$} & $11-20$ & 20 & 9.1 \\
\hline & more than 20 & 200 & 90.9 \\
\hline \multirow{4}{*}{$\begin{array}{l}\text { Number of } \\
\text { employees }\end{array}$} & more than 5000 & 20 & 9.1 \\
\hline & $1000-5000$ & 80 & 36.4 \\
\hline & $500-100$ & 80 & 36.4 \\
\hline & $1-500$ & 40 & 18.2 \\
\hline \multirow{3}{*}{$\begin{array}{l}\text { Total sales in } \\
2015 \text { (unit: } \\
\text { Yuan) }\end{array}$} & $50-100 \mathrm{~m}$ & 40 & 18.2 \\
\hline & $100-500 \mathrm{~m}$ & 60 & 27.3 \\
\hline & more than 500 million & 120 & 54.5 \\
\hline \multirow{4}{*}{ Age categories } & $20-30$ & 65 & 29.5 \\
\hline & $31-40$ & 65 & 29.5 \\
\hline & $41-50$ & 76 & 34.5 \\
\hline & $51-70$ & 14 & 6.4 \\
\hline \multirow{3}{*}{ education } & Associate degree & 1 & 0.5 \\
\hline & bachelor's degree & 146 & 66.4 \\
\hline & Master's degree or above & 73 & 33.2 \\
\hline \multirow{4}{*}{$\begin{array}{l}\text { period of } \\
\text { service in the } \\
\text { company }\end{array}$} & $1-5$ & 53 & 24.1 \\
\hline & $5-10$ & 70 & 31.8 \\
\hline & $10-15$ & 15 & 6.8 \\
\hline & more than 15 & 82 & 37.3 \\
\hline \multirow{4}{*}{$\begin{array}{c}\text { period of } \\
\text { service in the } \\
\text { current position }\end{array}$} & $1-5$ & 129 & 58.6 \\
\hline & $5-10$ & 78 & 35.5 \\
\hline & $10-15$ & 10 & 4.5 \\
\hline & more than 15 & 3 & 1.4 \\
\hline
\end{tabular}

B. Operationalization of Constructs and Instrument Validation 
TABLE II: NUMBER OF ADOPTED ITEMS AND SOURCES

\begin{tabular}{|c|c|c|c|c|}
\hline Main Variables & Main Variables & Number Of Items & Code Of Items & Reference \\
\hline \multirow{3}{*}{ Hardware } & \multirow{3}{*}{$\mathrm{H}$} & \multirow{3}{*}{3} & H1 & \multirow{3}{*}[26]{,$[27]$} \\
\hline & & & $\mathrm{H} 2$ & \\
\hline & & & $\mathrm{H} 3$ & \\
\hline \multirow{4}{*}{ Software } & \multirow{4}{*}{$S$} & \multirow{4}{*}{4} & $\mathrm{~S} 1$ & \multirow{4}{*}[28]{$-[30]$} \\
\hline & & & $\mathrm{S} 2$ & \\
\hline & & & S3 & \\
\hline & & & $\mathrm{S} 4$ & \\
\hline \multirow{3}{*}{ Network } & \multirow{3}{*}{$\mathrm{N}$} & \multirow{3}{*}{3} & N1 & \multirow{3}{*}[31]{,$[32]$} \\
\hline & & & $\mathrm{N} 2$ & \\
\hline & & & N3 & \\
\hline \multirow{4}{*}{ Knowledge Management } & \multirow{4}{*}{$\mathrm{KM}$} & \multirow{4}{*}{4} & KM1 & \multirow{4}{*}[33]{} \\
\hline & & & KM2 & \\
\hline & & & KM3 & \\
\hline & & & KM4 & \\
\hline \multirow{4}{*}{ Product Design } & \multirow{4}{*}{ PD } & \multirow{4}{*}{4} & PD1 & \multirow{4}{*}[34]{$-[38]$} \\
\hline & & & PD2 & \\
\hline & & & PD3 & \\
\hline & & & PD4 & \\
\hline
\end{tabular}

TABLE III: INTER-ITEM CORRELATION MATRIX

\begin{tabular}{|c|c|c|c|c|c|c|c|c|c|c|c|c|c|c|c|c|c|c|}
\hline PD4 & PD3 & $\mathrm{PD} 2$ & PD1 & $\mathrm{KM} 4$ & $\mathrm{KM} 3$ & $\mathrm{KM} 2$ & KM1 & N3 & N2 & N1 & $\$ 4$ & $\mathrm{S3}$ & S2 & $\$ 1$ & $\mathrm{HB}$ & $\mathrm{H} 2$ & $\mathrm{H1}$ & \\
\hline $680^{\circ}$ & $598^{*}$ & $547^{20}$ & $587^{20}$ & $695^{\prime \prime}$ & $.718^{21}$ & $845^{\prime \prime}$ & $598^{\prime \prime}$ & $.785^{\prime \prime}$ & $.737^{\prime \prime}$ & $570^{\circ 12}$ & $542^{\prime \prime}$ & $.471^{\prime \prime}$ & $518^{\prime \prime}$ & $617^{27}$ & $544^{\prime \prime}$ & $852^{\prime \prime \prime}$ & & $\mathrm{HI}$ \\
\hline $604^{14}$ & $503^{*}$ & $501^{*}$ & $528^{44}$ & $658^{+4}$ & $691^{*}$ & $775^{4 *}$ & $499^{-1}$ & $715^{4+}$ & $.642^{4+}$ & $477^{44}$ & $459^{47}$ & $390^{\circ}$ & $420^{14}$ & $556^{4}$ & $567^{4+}$ & 1 & & 12 \\
\hline $544^{\prime \prime}$ & $550^{\circ}$ & $344^{\prime \prime}$ & $398^{21}$ & $562^{\prime \prime}$ & $463^{\prime \prime}$ & $499^{\prime \prime}$ & $278^{-1}$ & $.567^{20}$ & $506^{\circ}$ & $275^{\circ}$ & $371^{*}$ & $248^{\prime \prime}$ & $.393^{\alpha+}$ & $418^{12}$ & 1 & & & $\mathrm{H3}$ \\
\hline $687^{24}$ & $574^{* 2}$ & $.575^{10}$ & $766^{12}$ & $815^{27}$ & $775^{10}$ & $688^{27}$ & $701^{2}$ & $788^{21}$ & $.735^{21}$ & $501^{*}$ & $766^{21}$ & $674^{\prime \prime}$ & $642^{21}$ & 1 & & & & S1 \\
\hline $707^{44}$ & $628^{*}$ & $468^{-4}$ & $550^{4+}$ & $572^{+4}$ & $537^{44}$ & $552^{H}$ & $533^{\prime \prime}$ & $649^{44}$ & $670^{44}$ & $483^{4+}$ & $549^{44}$ & $589^{-1}$ & 1 & & & & & S2 \\
\hline $608^{*}$ & $495^{\circ}$ & $.576^{10}$ & $738^{4}$ & $605^{*}$ & $598^{* 1}$ & $531^{*}$ & $645^{\prime \prime}$ & $707^{+1}$ & $.636^{\circ}$ & $481^{*}$ & $622^{\circ}$ & 1 & & & & & & $\mathrm{S3}$ \\
\hline $617^{* 4}$ & $543^{*}$ & $.552^{* 4}$ & $.750^{\circ+}$ & $741^{*}$ & $691^{*}$ & $584^{H}$ & $636^{\prime \prime}$ & $711^{* 4}$ & $740^{\circ}$ & $466^{*}$ & 1 & & & & & & & 54 \\
\hline $502^{* 4}$ & $477^{44}$ & $518^{-4}$ & $500^{4+}$ & $551^{*}$ & $686^{4}$ & $461^{4}$ & $563^{\prime \prime}$ & $599^{44}$ & $502^{4+}$ & 1 & & & & & & & & N1 \\
\hline $.754^{\prime \prime}$ & $674^{\circ}$ & $636^{\circ}$ & $.726^{\circ}$ & $.782^{*}$ & $.710^{*}$ & $.766^{\circ}$ & $.722^{-}$ & $.809^{24}$ & 1 & & & & & & & & & $\mathrm{~N} 2$ \\
\hline $860^{*-}$ & $750^{\circ-}$ & $738^{* 4}$ & $875^{40}$ & $862^{*}$ & $856^{\circ}$ & $820^{*-}$ & $691^{\prime \prime}$ & 1 & & & & & & & & & & $\mathrm{~N} 3$ \\
\hline $585^{* 4}$ & $557^{4+}$ & $508^{4+}$ & $.660^{44}$ & $694^{*}$ & $731^{* 4}$ & $581^{* 4}$ & & & & & & & & & & & & KM1 \\
\hline $692^{*}$ & $612^{*}$ & $614^{\prime \prime}$ & $681^{*}$ & $.713^{*}$ & $730^{\circ}$ & 1 & & & & & & & & & & & & $\mathrm{KM} 2$ \\
\hline $744^{\circ+}$ & $638^{*+}$ & $693^{*}$ & $762^{* 4}$ & $852^{\circ}$ & 1 & & & & & & & & & & & & & $\mathrm{KM} 3$ \\
\hline $790^{\circ 4}$ & $.706^{24}$ & $638^{4+}$ & $776^{4}$ & 1 & & & & & & & & & & & & & & $\mathrm{KM} 4$ \\
\hline $.739^{\circ}$ & $578^{\circ}$ & $.717^{n+}$ & 1 & & & & & & & & & & & & & & & PD1 \\
\hline $.713^{*}$ & $580^{\circ}$ & 1 & & & & & & & & & & & & & & & & PD2 \\
\hline $836^{+4}$ & & & & & & & & & & & & & & & & & & PD3 \\
\hline 1 & & & & & & & & & & & & & & & & & & PD4 \\
\hline
\end{tabular}

Note. Correlation is significant at $1 \%$ level (two-tailed).

The questionnaire was designed according to the concepts and indicators adopted in other questionnaire measures, various studies, and opinions of experts to development of questionnaire in accordance with the research requirements. Table II shows the dependable sources to benefit from concepts and indicators, symbols of each variable, and the number of items.

The inter-item correlation results were acceptable within .20-.90, which indicates the validity of the scale in Table III [39].

Table IV shows the $<.70$ reliability of all variable results using the scale of Cronbach's alpha coefficient.

The previous data are valid for statistical analysis. Table V indicates that all the average search (i.e., agree) agrees with the research objectives. Thus, the researched companies have an acceptable level of application of research variables [40].

TABLE IV: RELIABILITY STATISTICS

\begin{tabular}{ccc}
\hline variable & number of items & Alpha \\
\hline Hardware & 3 & 0.836 \\
\hline Software & 4 & 0.877 \\
\hline Network & 3 & 0.840 \\
\hline Knowledge Management & 4 & 0.910 \\
\hline Product design & 4 & 0.900 \\
\hline
\end{tabular}

TABLE V: ANALYSIS OF RESPONDENTS' RESPONSES ACCORDING TO THE Scale, Standard DeViation, ARITHMETIC MEAn, DEgREE of AGREEMENT, AND THE STRENGTH OF THE ANSWER TO THE VARIABLES OF STUDY

\begin{tabular}{|c|c|c|c|c|}
\hline item & Std. & $\begin{array}{c}\text { Mean } \\
\text { item }\end{array}$ & $\begin{array}{c}\text { agreement } \\
\text { degree of item }\end{array}$ & $\begin{array}{c}\text { answer strength to } \\
\text { the variables }\end{array}$ \\
\hline $\mathrm{H} 1$ & .501 & 4.52 & strongly agreed & 4.4394 \\
\hline $\mathrm{H} 2$ & .536 & 4.49 & strongly agreed & strongly agreed \\
\hline $\mathrm{H} 3$ & .645 & 4.31 & strongly agreed & \\
\hline S1 & .809 & 3.77 & agree & 3.9341 AGREE \\
\hline $\mathrm{S} 2$ & .712 & 4.21 & strongly agreed & \\
\hline S3 & .771 & 3.94 & agree & \\
\hline S4 & .815 & 3.81 & agree & \\
\hline N1 & .813 & 3.85 & agree & 3.5758 AGREE \\
\hline $\mathrm{N} 2$ & .883 & 3.53 & agree & \\
\hline N3 & 1.061 & 3.35 & agree & \\
\hline KM1 & .705 & 3.75 & agree & 3.7375 AGREE \\
\hline KM2 & .690 & 3.61 & agree & \\
\hline KM3 & .753 & 3.85 & agree & \\
\hline KM4 & .857 & 3.74 & agree & \\
\hline PD1 & .658 & 3.93 & agree & 4.105 AGREE \\
\hline PD2 & .682 & 4.03 & agree & \\
\hline PD3 & .582 & 4.28 & strongly agreed & \\
\hline PD4 & .685 & 4.18 & agree & \\
\hline
\end{tabular}

\section{FINDINGS/DISCUSSION}


Table VI shows the results of the simple linear regression between hardware (independent variable) and knowledge management (dependent variable). A significant positive correlation exists at $\alpha=.01$ wherein $R=.767$. The variance to knowledge management by $60 \%$ back to hardware, in accordance with $\mathrm{R}^{2}=.589$, indicates that the hardware affects knowledge management and proves a significant effect that $\mathrm{F}(1,219)>\mathrm{F}$ scheduled. The significant regression coefficient of hardware $\beta=1.049$, and T calculated $>$ T tabular at $\alpha=.01$ and $.99=$ degree of confidence. These results validate the hypothesis and is consistent with the literature [41], [42].

Table VI presents the results of the hypothesis with respect to software (independent variable) and knowledge management (dependent variable). Results show that $\mathrm{R}=.845$, $\mathrm{R}^{2}=.714, \mathrm{~F}(1,218)=544.208, \mathrm{~T}=23.328$, and $\beta=.850$ when $\alpha=.01$, and the degree of confidence $=.99$. All acceptable results indicate the presence of a strong positive statistical correlation, and software change in knowledge management $(85 \%)$ indicates the presence of the effect relationship and proves the validity of this effect that $\mathrm{F}$ Calculated $>\mathrm{F}$ tabular. Moreover, coefficient regression software $\beta$ is proven significant, where $\mathrm{T}$ calculated $>\mathrm{T}$ tabular. Thus, we validate the hypothesis, which is also supported literature [43], [44].

There is a strong correlation significant between the networks(independent variable) and the knowledge management (dependent variable) that through $(\mathrm{R}=.922)$, where the change in knowledge management is at $60 \%$ back to the networks, which prove the effect of networks on knowledge management and confirms the validity of the regression model $\mathrm{F}(1,218)>\mathrm{F}$ tabular. Moreover, $\mathrm{T}$ calculated $>\mathrm{T}$ tabular, which emphasizes the significant regression coefficient of networks $\beta=.784$ at $\alpha=.01$ and the degree of confidence $=.99$, as shown in Table 6 . The results emphasize the true of acceptance of the hypothesis, which is confirmed by references [45], [46].

TABLE VI: RESULTS OF MULTIPLE REGRESSIONS ANALYSIS

\begin{tabular}{|c|c|c|c|c|c|}
\hline \multirow{2}{*}{\multicolumn{2}{|c|}{ Theses4 }} & & & & \\
\hline & & Theses1 & Theses2 & Theses3 & Theses4 \\
\hline \multicolumn{2}{|r|}{ independent } & $\mathrm{H}$ & $S$ & $\mathrm{~N}$ & KM \\
\hline \multicolumn{2}{|r|}{$\mathrm{R}$} & .767 & .845 & .922 & .857 \\
\hline \multicolumn{2}{|r|}{$\mathrm{R}^{2}$} & .589 & .714 & .850 & .735 \\
\hline \multicolumn{2}{|r|}{ DF } & $(218,1)$ & $(218,1)$ & $(218,1)$ & $(218,1)$ \\
\hline \multicolumn{2}{|r|}{ F tabular } & 6.63 & 6.63 & 6.63 & 6.63 \\
\hline \multicolumn{2}{|c|}{ F Calculated } & 311.901 & 544.208 & 1231.622 & 605.438 \\
\hline \multicolumn{2}{|r|}{ sig } & .000 & .000 & .000 & .000 \\
\hline \multirow{4}{*}{ 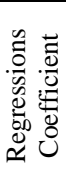 } & dependent & KM & $\mathrm{KM}$ & KM & PD \\
\hline & $\beta$ & 1.049 & .850 & .784 & .734 \\
\hline & $\mathrm{T}$ tabular & 2.581 & 2.581 & 2.581 & 2.581 \\
\hline & T Calculated & 17.661 & 23.328 & 35.094 & 24.606 \\
\hline
\end{tabular}

Simple linear regression was used to clarify the relationship between knowledge management as an independent variable and product design as a dependent variable, as shown in Table $6 . \mathrm{R}=.857$, which indicates a strong positive correlation that is statistically significant at $\alpha=1 \%$ and degree of confidence $=99 \% . R^{2}=.735$ represents the variation ratio that moves product design back to knowledge management. That is, knowledge management affects the product design and proves the validity of the regression model, $\mathrm{F}(1,218)$ calculated $>\mathrm{F}$ tabular. However, it also proves a significant regression coefficient of knowledge management $\beta=.734$, which supports $\mathrm{T}$ calculated $>\mathrm{T}$ tabular by showing that we can only accept the hypothesis as confirmed by references [47]-[49].

The validity of the recent hypothesis is tested using multiple regression. The validity of the regression model is tested using the F-test, where F Calculated is $219.260>\mathrm{F}$ tabular is 3.32 at degree of freedom $(4,215)$ and $\alpha=1 \%$, which indicates the validity of the model to measure the effects of hardware, software, networks, and knowledge management (independent variables) on product design (dependent variable), as shown in Table VII.

TABLE VII: THESES 5, ANOVAA

\begin{tabular}{|cc|c|c|c|c|c|}
\hline \multirow{2}{*}{ Model } & $\begin{array}{c}\text { Sum of } \\
\text { Squares }\end{array}$ & df & $\begin{array}{c}\text { Mean } \\
\text { Square }\end{array}$ & F & Sig. \\
\hline \multirow{2}{*}{1} & Regression & 57.692 & 4 & 14.423 & 219.260 & $.000^{\mathrm{b}}$ \\
& Residual & 14.143 & 215 & .066 & & \\
\hline
\end{tabular}

a. Dependent Variable: Product Design

b. Predictors: (Constant), Knowledge Management, Hardware, Software, Network

After validation, the regression model measures the impact that has extracted the $\mathrm{R}^{2}$ cumulatively and $\mathrm{R}$. Table 8 shows that all statistically significant correlations are positive at $\alpha=1 \%$, and the variation that gets the product design increases. Thus, the independent variables have a positive impact on product design, which validates the hypothesis and confirms references [50]-[54].

TABLE VIII: THESES 5, MODEL SUMMARY

\begin{tabular}{|c|c|c|c|c|}
\hline Model & R & R Square & $\begin{array}{c}\text { Adjusted R } \\
\text { Square }\end{array}$ & $\begin{array}{c}\text { Std. Error of the } \\
\text { Estimate }\end{array}$ \\
\hline 1 & $.685^{\mathrm{a}}$ & .469 & .466 & .41846 \\
2 & $.856^{\mathrm{b}}$ & .733 & .730 & .29745 \\
3 & $.894^{\mathrm{c}}$ & .799 & .797 & .25824 \\
4 & $.896^{\mathrm{d}}$ & .803 & .799 & .25648 \\
\hline
\end{tabular}

a. Predictors: (Constant), Hardware

b. Predictors: (Constant), Hardware, Software

c. Predictors: (Constant), Hardware, Software, Network

d. Predictors: (Constant), Hardware, Software, Network, Knowledge

Management

\section{CONCLUSION/IMPLICATIONS}

The results of the study reveal that the surveyed companies rely on IT components and knowledge management in their product design to achieve corporate objectives and customer satisfaction. The results prove a strong correlation and effect among IT component and knowledge management on product design.

\section{ACKNOWLEDGMENT}

I. Mariam thanks to Abd UL-Rada Nasser M. AL-Malek and Waleed Alaa Faraj to illustrate some things.

\section{REFERENCES}

[1] S. A. Pedro and C. N. Juan-Gabriel, "New ICTs for knowledge management in organizations," Journal of Knowledge Management, vol. 20, issue 3, pp. 417-422, 2016.

[2] I. C. Hsu and R. Sabherwal, "From intellectual capital to firm performance: The mediating role of knowledge management capabilities," IEEE Transactions on Engineering Management, vol. 58, no. 4, pp. 626-642, 2011 
[3] L. Moffat and N. Archer, "Knowledge management in production alliances," Information Systems and e-Business Management, vol.2, no. 2-3, pp. 241-267, 2004

[4] N. Karaarslan and E. Gundogar, "An application for modular capability-based ERP software selection using AHP method," The International Journal of Advanced Manufacturing Technology, vol. 42, no. 9-10, pp. 1025-1033, 2009.

[5] P. Meža, "Product management and knowledge management," in Proc. Global Empowerment of the Management, Knowledge and Learning International Conference on Knowledge and Learning, pp. 859-867, 2012.

[6] I. Saad, M. Grundstein, and C. Rosenthal-Sabroux, "Challenges in Capitalizing Knowledge in Innovative Product Design Process," Université Paris-Dauphine, 2009.

[7] L. S. Ling and U. C. Eze, "The impact of information infrastructure capabilities on knowledge manipulation skills: A conceptual framework," Communications of the IBIMA, vol. 1, pp. 219-227, 2008.

[8] K. S. Mathew, "Impact of information communication technology (ICT) on professional development and educational needs of library professionals in the universities of Kerala," 2011.

[9] J. F. Cohen and K. Olsen, "The impacts of complementary information technology resources on the service-profit chain and competitive performance of South African hospitality firms," International Journal of Hospitality Management, vol. 34, pp. 245-254, 2013.

[10] H. Tanriverdi, "Information technology relatedness, knowledge management capability, and performance of multibusiness firms," MIS Quarterly, pp. 311-334, 2005.

[11] I. Nonaka, P. Reinmoeller, and D. Senoo, "Integrated IT systems to capitalize on market knowledge, knowledge creation: A source of value," 2000.

[12] K. S. Mathew, "Impact of information communication technology (ICT) on professional development and educational needs of library professionals in the universities of Kerala," 2011.

[13] K. M. Hawajreh and A. Sharabati, "The Impact of Information Technology on Knowledge Management Practices," International Journal of Business, Humanities and Technology, vol. 2, no. 7, pp. 32-46, 2012.

[14] K. M. Hawajreh and A. Sharabati, "The impact of information technology on knowledge management practices," International Journal of Business, Humanities and Technology, vol. 2, no. 7, 2012.

[15] V. Dignum and F. Dignum, "The knowledge market: Agent-mediated knowledge sharing," International Central and Eastern European Conference on Multi-Agent Systems, Springer Berlin Heidelberg, Jun. 2003.

[16] D. Walters, Operations Strategy, Palgrave Macmillan, New York, 2002.

[17] M. D. Singh, R. Shankar, R. Narain, and A. Kumar, "Survey of knowledge management practices in Indian manufacturing industries," Journal of Knowledge Management, vol. 10, no. 6, 2006.

[18] D. J. Xue, T. Y. Gao, Y. Pan, and G. Y. Mu, "Research of knowledge management during products design process," Applied Mechanics and Materials, Trans Tech Publications, vol. 433, pp. 2476-2479, 2013.

[19] S. C. Voelpel, H. Pierer, and C. K. Streb, "Mobilizing organizations for innovation and value creation: An integrated model of the mobile company," Journal of Knowledge Management, vol. 10, no. 6, pp. 5-21, 2006.

[20] C. Y. Jang, C. Steinfield, and B. Pfaff, "Supporting awareness among virtual teams in a web-based collaborative system: the teamSCOPE system," ACM Siggroup Bulletin, vol. 21, no. 3, pp. 28-34, 2000.

[21] M. Chamorro-Koc and V. Popovic, "Experiential knowledge representation and the design of product usability," 2009.

[22] X. F. Zha and R. D. Sriram, "Platform-based product design and development: A knowledge-intensive support approach," Knowledge-Based Systems, vol. 19, no. 7, pp. 524-543, 2006.

[23] H. O. Aderemi, T. O. Oyebisi, and A. A. Adeniyi, "Development of a measure for technological capability in the information and communications technology industry in Nigeria," Global Network for Economics of Learning, Innovation, and Competence Building Systems (GLOBELICS), Dakar, Senegal, October 2009.

[24] J. Wu, Y. Wang, and S. Li, "Search depth, knowledge characteristics, and innovation performance," Journal of Chinese Management, vol. 1, no. 1, p. 1, 2014.

[25] K. Nogeste and D. H. T. Walker, "Using knowledge management to revise software-testing processes," Journal of Workplace Learning, vol 18 , issue 1, pp.6-27, 2006.

[26] A. Bouajila, J. Zeppenfeld, W. Stechele, A. Bernauer, O. Bringmann, W. Rosenstiel, and A. Herkersdorf, "Autonomic system on chip platform," Organic Computing - A Paradigm Shift for Complex Systems, Springer Basel, pp. 413-425, 2011.

[27] P. P. Tallon, "Inside the adaptive enterprise: an information technology capabilities perspective on business process agility," Information Technology and Management, vol. 9, no. 1, pp. 21-36, 2008.

[28] A. Buchalcevova, "Research of the use of Agile methodologies in the Czech Republic," Information Systems Development, Springer US, pp. 51-64, 2009.

[29] D. Marghescu, "Usability evaluation of information systems: A review of five international standards," Information Systems Development, Springer US., pp. 131-142, 2009.

[30] P. P. Tallon, "Inside the adaptive enterprise: an information technology capabilities perspective on business process agility," Information Technology and Management, vol. 9, no.1, pp. 21-36, 2008.

[31] K. S. Mathew, "Impact of information communication technology (ICT) on professional development and educational needs of library professionals in the universities of Kerala," 2011.

[32] P. P. Tallon, "Inside the adaptive enterprise: an information technology capabilities perspective on business process agility," Information Technology and Management, vol. 9, no. 1, pp. 21-36, 2008.

[33] J. S. Chen and E. Y. Li, "The effect of information technology adoption and design customisation on the success of new product development," International Journal of Electronic Business, vol. 8, no. 6, pp. 550-578, 2010.

[34] D. Baxter, J. Gao, K. Case, J. Harding, B. Young, S. Cochrane, and S. Dani, "A framework to integrate design knowledge reuse and requirements management in engineering design," Robotics and Computer-Integrated Manufacturing, vol. 24, no. 4, pp. 585-593, 2008.

[35] J. S. Chen and E. Y. Li, "The effect of information technology adoption and design customisation on the success of new product development," International Journal of Electronic Business, vol. 8, no. 6, pp. 550-578, 2010.

[36] R. Chiva and J. Alegre, "Investment in design and firm performance: The mediating role of design management," Journal of Product Innovation Management, vol. 26, no. 4, pp. 424-440, 2009.

[37] Y. Fu Qiu, Y. Ping Chui, and M. G. Helander, "Cognitive understanding of knowledge processing and modeling in design," Journal of Knowledge Management, vol. 12, no. 2, pp. 156-168, 2008.

[38] Q. Fu et al., "Knowledge identification and management in product design," Journal of Knowledge Management, vol. 10, no. 6, pp. 50-63, 2006.

[39] J. F. Hair, W. C. Black, B. J. Babin, and R. E. Anderson, Multivariate Data Analysis, $7^{\text {th }}$ Ed., Pearson Prentice Hall, 2010.

[40] R. Likert, "A technique for the measurement of attitudes," Archives of Psychology, 1932.

[41] K. M. Hawajreh and A. Sharabati, "The Impact of Information Technology on Knowledge Management Practices," International Journal of Business, Humanities and Technology, vol. 2, no. 7, pp. 32-46, 2012.

[42] N. Karaarslan and E. Gundogar, "An application for modular capability-based ERP software selection using AHP method," The International Journal of Advanced Manufacturing Technology, vol. 42, no. 9-10, pp. 1025-1033, 2009.

[43] K. M. Hawajreh and A. Sharabati, "The Impact of Information Technology on Knowledge Management Practices," International Journal of Business, Humanities and Technology, vol. 2, no. 7, pp. 32-46, 2012.

[44] N. Karaarslan and E. Gundogar, "An application for modular capability-based ERP software selection using AHP method," The International Journal of Advanced Manufacturing Technology, vol. 42, no. 9-10, pp. 1025-1033, 2009.

[45] K. M. Hawajreh and A. Sharabati, "The Impact of Information Technology on Knowledge Management Practices," International Journal of Business, Humanities and Technology, vol. 2, no. 7, pp. 32-46, 2012.

[46] N. Karaarslan and E. Gundogar, "An application for modular capability-based ERP software selection using AHP method," The International Journal of Advanced Manufacturing Technology, vol. 42, no. 9-10, pp. 1025-1033, 2009.

[47] D. Baxter, J. Gao, K. Case, J. Harding, B. Young, S. Cochrane, and S. nDani, "A framework to integrate design knowledge reuse and requirements management i engineering design," Robotics and Computer-Integrated Manufacturing, vol. 24, no. 4, pp. 585-593, 2008.

[48] M. Chamorro-Koc and V. Popovic, "Experiential knowledge representation and the design of product usability," 2009. 
[49] J. S. Chen and E. Y. Li, "The effect of information technology adoption and design customisation on the success of new product development," International Journal of Electronic Business, vol. 8, no. 6, pp.550-578, 2010.

[50] S. A. Pedro et al., "New ICTs for Knowledge Management in Organizations," Journal of Knowledge Management, vol. 20, issue 3, pp. 417-422, 2016.

[51] Z. Xutang et al., "A knowledge reuse-based computer-aided fixture design framework," Assembly Automation, vol. 34, issue 2, pp. $169-181,2014$

[52] K. M. Hawajreh and A. Sharabati, "The Impact of Information Technology on Knowledge Management Practices," International Journal of Business, Humanities and Technology, vol. 2, no. 7, pp. 32-46, 2012.

[53] K. S. Mathew, "Impact of information communication technology (ICT) on professional development and educational needs of library professionals in the universities of Kerala," 2011
[54] K. Nogeste and D. H. T. Walker, "Using knowledge management to revise software-testing processes," Journal of Workplace Learning, vol. 18, issue 1, pp.6-27, 2006

Mariam Ibrahim is Ph.D. student of the Department of Business Management, College of Management, Huazhong University of Science and Technology, China.

Her major research field is operation and production management, information technology, knowledge management.

Ma Huimin is the professor in the Department of Information Management, School of Management, Huazhong University of Science and Technology. Additionally he is also the vice director of the Electronic Business Center of HUST in 2004. His major research field is the application of information technology in corporation, especially the application of electronic business. 